\title{
PROTECTING LEGAL RightS WHEN THINGS GO WRONG: LEGAL RECOURSE IF MANDATORY FORTIFICATION OF A FOOD WERE TO HARM HUMAN HEALTH
}

\author{
JOE LEDERMAN ${ }^{*}$
}

\begin{abstract}
Food laws can encompass considerations that extend beyond food safety. The recent food standard mandating the fortification of flour with folic acid in Australia illustrates the legal problems and legal risks when governments introduce food standards that aim to medicinalise the population through the food supply despite a lack of scientific consensus. Legal analysis of the process by which the folic acid fortification was introduced into flour in Australia demonstrates legal inadequacies, administrative and policy failures, as well as flaws in safety assumptions. An analysis of the restrictions on legal rights and remedies for any adversely affected consumers seeking legal redress, and the existence of statutory immunities for governments, demonstrates a need for legal reform and changes in policy development processes.
\end{abstract}

\section{INTRODUCTION}

The traditional governmental approach to the development of food regulations ${ }^{1}$ and food standards ${ }^{2}$ has been to ensure that the food is not unsafe

\footnotetext{
* Managing Principal of FoodLegal - Lawyers and Consultants (www.foodlegal.com.au), Adjunct Professor of Food Law at Deakin University. The author would like to thank $\mathrm{Mr}$ Charles Fisher, a FoodLegal lawyer colleague, for his constructive suggestions in the author's preparation of this paper.

${ }^{1}$ See, for example, the first object in s 3 of the Food Act 1984 (Vic) is: '(a) to ensure food for sale is both safe and suitable for human consumption'.

${ }^{2}$ For example, the Australia New Zealand Food Standards Code.
} 
and that it is not adulterated by unauthorised or excessive levels of chemical additives or residues. ${ }^{3}$

More recent government food policy in Australia has broadened this approach ${ }^{4}$ so that the Australia New Zealand Food Standards Code ('the Food Standards Code') includes food standards that have been designed to improve the health of food consumers in Australia by fortification of particular foods selected as carriers to medicate the population. ${ }^{5}$

This paper uses for a case study the introduction of the new clause 4(2)(a) of food standard 2.1.1 of the Food Standards Code which requires the mandatory fortification with folic acid of wheat flour used for making bread ("the mandatory folic acid fortification'). ${ }^{6}$ This was introduced by Food Standards Australia New Zealand (FSANZ) after its consideration of Proposal P295 and has been gazetted to take effect on 13 September 2009. The case of mandatory folic acid fortification can be distinguished from previous mandatory fortification implementations. ${ }^{8}$

This paper aims to illustrate that, unless there are adequate legal safeguards in place, the mandatory fortification of a food may leave Australian consumers legally vulnerable in the event that it has an adverse impact on any sector of the population. The enactment of the Food Standard for mandatory fortification of bread-making flour with folic acid has occurred at a time when the legal rights and remedies of consumers have been circumscribed by a

\footnotetext{
${ }^{3}$ For example, the first object of the Food Standards Australia New Zealand Act 1991 (Cth) is to achieve: '(a) a high degree of consumer confidence in the quality and safety of food produced, processed, sold or exported from Australia and New Zealand.'

${ }^{4}$ On 1 January 1991, the mandatory fortification of bread-making flour with thiamin to lower the incidence of Wernicke-Korsakoff syndrome was made a legal requirement under the previous Australia New Zealand Food Standards Code. On 13 September 2008, Proposal P295 'Consideration of Mandatory Fortification with Folic Acid' was gazetted. On 9 October 2008, Proposal P1003 'Mandatory Iodine Fortification for Australia' to address the reemergence of iodine deficiency in Australia was gazetted.

${ }^{5}$ The Macquarie Dictionary defines 'medicate' as ' 1 . to treat with medicine or medicaments. 2. to impregnate with a medicine'.

$6<$ http://www.foodstandards.gov.au/_srcfiles/Standard_2_1_1_Cereals_v112.pdf $>$ at 28 October 2009

${ }^{7}$ Clause 4 of Standard 2.1.1, with effect from 13th September 2009, states: 'Wheat flour for making bread must contain - (a) no less than $2 \mathrm{mg} / \mathrm{kg}$ and no more than $3 \mathrm{mg} / \mathrm{kg}$ of folic acid; and (b) no less than $6.4 \mathrm{mg} / \mathrm{kg}$ of thiamin.'

${ }^{8}$ For example, the health effects of iodine fortification on the wider and diverse population groupings has been well documented over a significantly longer time period, and the administrative processes undertaken by the standard-setting agency would not appear to be as susceptible to claims of administrative law flaws or lack of due diligence as in the case of the mandatory folic acid fortification.
} 
range of other laws, limiting the recourse of consumers to legal remedies if things were to go wrong.

The author identifies serious legal failures in the process of the development of this food standard and also examines the prospect of further legal failures that are likely to occur in the event that an Australian consumer suffers any adverse consequence. This is notwithstanding the potential for health benefits to be derived by others. Recommendations for additional legal reform are proposed in this paper.

\section{The Science And Decision-MaKing Process BEHIND MANDATORY FOLIC ACID FORTIFICATION}

\section{A Driving Force for the Implementation of Mandatory Folic Acid Fortification}

Folate, a form of water-soluble Vitamin B9, is critical for cell division and growth, and for DNA repair processes. ${ }^{9}$ Low levels of folate in pregnant women have been linked to neural tube defects (NTDs). Studies suggest that an elevated level of folate during the periconceptional period, the time just before and just after a woman becomes pregnant, reduces the risk of NTDs. ${ }^{10}$

In the early 1990s, Professor Fiona Stanley became a leading advocate for a range of health promotion activities to promote increased periconceptional folate intake. ${ }^{11}$ These activities included informing women of the association between folate and NTDs and encouraging women to increase their dietary intake of folate and to take folic acid supplements. ${ }^{12}$ In 1996, voluntary

\footnotetext{
${ }^{9}$ FSANZ, 'Final Assessment Report Proposal P295 Consideration of Mandatory Fortification with Folic Acid' (4 October 2006) ('Final Assessment Report') 6.

${ }^{10}$ See Carol Bower and Fiona Stanley, 'Periconceptional vitamin supplementation and neural tube defects; evidence from a case-control study in Western Australia and a review of recent publications,' (1992) 49 Journal of Epidemiology Community Health 157-61. See also Carol Bower, L Blum, C Watson et al, 'Folate and the prevention of neural tube defects: Evaluation of a health promotion project in Western Australia' (1996) 11 Health Promotion International 177-87.

11 Professor Fiona Stanley is a world pioneer in her findings identifying the relationship between having a lack of folate and the prevalence of NTDs, especially in the indigenous Australian population of Western Australia.

${ }^{12}$ Carol Bower, 'Primary prevention of neural tube defects with folate in Western Australia: the value of the Western Australian Birth Defects Registry' (2006) 46 Congenital Anomalies 118.
} 
fortification of certain foods with folic acid was approved with a maximum level of $100 \mu \mathrm{g}$ of folic acid per serve. ${ }^{13}$

The health promotion activities, folate supplements and voluntary folic acid fortification of the 1990s, saw a 30 per cent decrease in the incidence of NTDs for non-indigenous infants. ${ }^{14}$ However, the rates of NTDs in indigenous Australian infants remained as high as before the pre-promotion era. ${ }^{15}$

Due to the link between folate, NTDs, and the limited use of folate supplements on a voluntary basis (because of socioeconomic and demographic disparities), mandatory folic acid fortification of a staple food was seen to present a solution for preventing NTDs. ${ }^{16}$ According to an Australian-authored paper comparing the effects of mandatory fortification in the United States, Chile and Canada, there had been significant reductions in NTDs after mandatory folic acid fortification of breads and cereals in those countries. ${ }^{17}$ According to these studies, mandatory folic acid fortification 'had resulted in a $30 \%$ reduction of neural tube defects' in the United States every year, ${ }^{18}$ and a 70 per cent reduction in Chile ${ }^{19}$ and a 50 per cent reduction in Canada. ${ }^{20}$

\footnotetext{
${ }^{13}$ Ibid 119.

${ }^{14}$ Ibid.

${ }^{15}$ Ibid 120 .

${ }^{16}$ Ibid.

${ }^{17}$ Glen Maberly and Fiona Stanley, 'Mandatory fortification of flour with folic acid: an overdue public health opportunity' (2005) 183(7) Medical Journal of Australia 342-3. Also available at <http:www.mja.com.au/public/issues/183_07_031005/mab10716_fm.html\#0_ i1091600> at 28 October 2009.

${ }^{18}$ Ibid.

${ }^{19} \mathrm{E}$ E Castilla et al, 'Latin American Collaborative Study of Congenital Malformations: Preliminary data on changes in neural tube defect prevalence rates after folic acid fortification in South America' (2003) 123 American Journal of Human Genetics 123-8.

${ }^{20}$ G P Oakley et al, 'Scientific evidence supporting folic acid fortification of flour in Australia and New Zealand' (2004) 70 Birth Defects Research (Part A) Clinical and Molecular Teratology 838-41.
} 


\section{B Recent Scientific Studies Expressing Concerns}

Lawrence has written:

Given that 20 million Australians will be exposed to significantly raised levels of synthetic folic acid for the first time in evolutionary history, it is of importance to consider its impact on the health of the wider population. ${ }^{21}$

While increased folic acid intake is understood to be associated with the reduction in the incidence of NTDs, ${ }^{22}$ recent studies have emerged suggesting that elevated levels of folic acid might cause serious illness or mask the symptoms of other serious health conditions. ${ }^{23}$

Numerous peer-reviewed scientific studies have illustrated the health risks associated with elevated folic acid levels. ${ }^{24}$ A European study has observed a significant increased risk of colorectal cancer in individuals with the highest folate intakes over a 4.2 year period. ${ }^{25}$ One US study has revealed that high folate intakes attributed to supplemental folic acid were associated with an increase in breast cancer. ${ }^{26}$ Another US study has found that there was an inverse relationship between unmetabolised folic acid and a measure of immunity (natural killer cell cytotoxicity). ${ }^{27}$ Increasing folic acid intake may be related to the reduction of response to antifolate drugs used against

${ }^{21}$ Mark Lawrence, 'Mandatory fortification with folic acid: what would Hippocrates say?' (January - February 2007) 36: 1/2 Australian Family Physician 69.

${ }^{22}$ Australian Broadcasting Corporation Radio National, 'Interview by Terry Lane of Professor Fiona Stanley', The National Interest, 21 May $2005<\mathrm{http}: / /$ www.abc.net.au/rn/talks/ natint/stories/s131463.htm> at 7 November 2008. Terry Lane (interviewer): '.. when you find these vitamin deficiencies as causes of congential defects'. Professor Fiona Stanley (in response): 'It is actually not a deficiency Terry, that is the interesting thing. That's the really interesting thing. Well it seems (this is the theory we are working with at the moment) that women who are going to have a neural tube defect baby probably have some genetic problem in terms of their folate metabolism. And so if you eat a lot of folate, you can overcome whatever that defect is. Interesting isn't it? ... So you have to think about the genes and the environment and how they interact, and genes being switched on in development and then switched inappropriately'.

${ }^{23}$ Mark Lawrence, above n 21, 69.

${ }^{24}$ Mark Lawrence drew attention to these studies: ibid.

${ }^{25}$ B Van Guelpen, J Hultdin, I Johansson et al, 'Low folate levels may protect against colorectal cancer'(2006) 55 Gut Online 1461-66.

${ }^{26} \mathrm{R}$ Z Stolzenberg-Solomon, S C Chang, M F Leitzmann et al, 'Folate intake, alcohol use and postmenopausal breast cancer risk in the Prostate, Lung, Colorectal and Ovarian Cancer Screening Trial' (2006) 83 American Journal of Clinical Nutrition 895-904.

${ }^{27}$ A M Troen, B Mitchell, B Sorensen et al, 'Unmetabolised folic acid in plasma is associated with reduced natural killer cell cytotoxicity among postmenopausal women' (2006) 82 Journal of Nutrition 189-94. 
malaria, rheumatoid arthritis, psoriasis and cancer. ${ }^{28}$ The combination of high folate levels and low vitamin B-12 status may be associated with an increased risk of cognitive impairment and anaemia in the elderly, and in pregnant women, and may increase the risk of insulin resistance and obesity in their children. $^{29}$ A recent University of Adelaide study has linked extended supplemented folate intake in pregnancy with childhood asthma of the baby. ${ }^{30}$ A recent Norwegian study, published in the Journal of the American Medical Association, has identified predispositions to increased risks of cancer from folic acid intake. ${ }^{31}$

If any of the risks highlighted by these scientific studies are real, the consequence is that mandatory folic acid fortification exposes the entire population of Australia to these identified health risks associated with increased folic acid intake. A recent article in the American Journal of Clinical Nutrition has warned that nations considering folic acid fortification should be cautious and should stimulate further research to identify the effects of high intake levels of folic acid. ${ }^{32}$ Yet, according to Lawrence, Australia lacks the nutrition information systems that would be necessary to implement and monitor policy-making decisions for mandatory folic acid fortification. ${ }^{33}$

\section{The Role of Food Standards Australia New Zealand}

The primary statutory obligation of FSANZ is to consider proposals or applications for the development or variation of food standards for the Food

\footnotetext{
${ }^{28}$ A David Smith, Young-In Kim and Helga Refsum, 'Is folic acid good for everyone?' (2008) 87 American Journal of Clinical Nutrition 517.

${ }^{29}$ Ibid.

${ }^{30}$ M J Whitrow et al 'Effect of Supplemental Folic Acid in Pregnancy on Childhood Asthma: A Prospective Birth Cohort Study' American Journal of Epidemiology Advance Access published October 30, 2009.

${ }^{31}$ M Ebbing et al, 'Cancer Incidence and Mortality after Treatment with Folic Acid and Vitamin B12' (2009) 302(19) Journal of the American Medical Association 2152. Some important novel aspects of this study were that the trial was conducted in a country that had not permitted voluntary fortification of food with folic acid, and accordingly the baseline level of folate was low (even less than the recommended upper limits set by Australian food standard Standard 2.1.1, Clause 4); secondly, the study identified two subgroups of the population, smokers and people with the 677TT variant of the gene for MTHFR, who accounted for most of the increase in cancer. (It should be noted that these subgroups are quite common in the population).

${ }^{32}$ Above $\mathrm{n} 28$.

${ }^{33}$ Mark Lawrence, 'Unusual circumstances and complex challenges in folate debate' (2006) 30(1) Australian and New Zealand Journal of Public Health 82.
} 
Standards Code ${ }^{34}$ with the primary objective of protecting public health and safety. $^{35}$

While FSANZ generally acknowledges policy directions from superior policy-making bodies such as the Australia and New Zealand Food Regulation Ministerial Council ('Ministerial Council') before drafting the actual wording of a food standard or variation, FSANZ is legally obligated to make its own scientific assessment of public health risks. It does so after considering any submissions from members of the public or stakeholders, who are invited to participate in a consultative process managed by FSANZ before the wording of a food standard is finalised. ${ }^{36}$ Most importantly, the primary objective of FSANZ under the FSANZ Act 1991 (Cth) is to assess the safety of food through risk analysis in order to protect the health of the public.

\section{The Decision to Impose Mandatory Folic Acid Fortification}

On 28 May 2004, the Ministerial Council endorsed the Policy Guideline: Fortification of Foods with Vitamins and Minerals. This Policy Guideline set out the issues to be addressed by FSANZ and the policy requirements that needed to be complied with in the FSANZ assessment of permissions for the addition of vitamins and minerals in food. These included the requirement that a mandatory fortification should be implemented only in response to a demonstrated significant population health need, taking into account the severity and prevalence of the health problem, and that it should be implemented only if it is the most effective public health strategy to address the particular public health problem. ${ }^{37}$

This Policy Guideline did not refer specifically to folate or folic acid and did not express or imply any need for mandatory fortification of foods with certain vitamins or minerals. However, in May 2004, the Ministerial Council issued a communiqué stating that the Ministers agreed 'with FSANZ that mandatory fortification of food with iodine and folate, should be considered as a priority, ${ }^{38}$

\footnotetext{
${ }^{34}$ Food Standards Australia New Zealand Act 1991 (Cth) s 13 ('the FSANZ Act').

${ }^{35}$ Food Standards Australia New Zealand Act 1991 (Cth) s 18.

${ }^{36}$ FSANZ Act s 18(2).

${ }^{37}$ FSANZ, Policy Guideline: Fortification of Food with Vitamins and Minerals (28 May 2004) 2 .

${ }^{38}$ Australia and New Zealand Food Regulation Ministerial Council, 'Joint Communiqué: Food Ministers Protect Public Health, Support Industry Innovation’ (28 May 2004).
} 
On 20 October 2004, FSANZ released its Initial Assessment Report on Proposal P295 - 'Consideration of Mandatory Fortification with Folic Acid'. This report set out the specific objectives of FSANZ in relation to Proposal P295 which were both to determine the most effective way to increase the folate intake in women to reduce the occurrence of neural tube defects (NTDs) and to take into consideration the risks and benefits to the general population of increased dietary folate intake. ${ }^{39}$

According to the FSANZ Draft Assessment Report (released on 3 July 2006 although the public submissions were received considerably earlier, between October and December 2004), FSANZ had, in December 2004, asked the Food Regulation Standing Committee ('FRSC') of the Ministerial Council for advice on the following two issues:

1) whether mandatory fortification with folic acid is the most effective public health strategy; and

2) how to establish a health monitoring and review system in support of mandatory fortification. ${ }^{40}$

The FRSC then referred the questions to the Australian Health Ministers' Advisory Council ('AHMAC') and the Australian Health Ministers' Conference ('AMHC'). AHMAC convened an Expert Panel to address these issues. According to the FSANZ Draft Assessment Report, the Ministerial Council, in October 2005, 'noted the advice of AHMAC and AHMC that mandatory fortification with folic acid is an effective public health strategy subject to clinical safety and cost-effectiveness' (This Ministerial Council direction was not published). ${ }^{41}$ The Expert Panel's report, upon which the advice of AHMAC and AHMC were based, had been dated June 2005. A Final Assessment Report by FSANZ was released on 4 October 2006.

On 25 October 2006, the members of the Ministerial Council issued a Communiqué stating 'their commitment to reduce the number of neural tube defects through mandatory fortification with folic acid as quickly as possible'. ${ }^{42}$

\footnotetext{
39 FSANZ, 'Initial Assessment Report for Proposal P295 - Consideration of Mandatory Fortification with Folic Acid' (20 October 2004) ('Initial Assessment Report') 11.

40 FSANZ, 'Draft Assessment Report for Proposal P295 - Consideration of Mandatory Fortification with Folic Acid' (3 July 2006) ('Draft Assessment Report') 5.

${ }^{41}$ Ibid.

${ }^{42}$ Australia and New Zealand Food Regulation Ministerial Council, 'Joint Communiqué: Food Ministers Protect Public Health and Support Industry Innovation’ 25 October 2006.
} 
In November 2006, the Ministerial Council announced that FSANZ had been asked to review the proposed Standard with particular attention to technical aspects of the implementation of the Standard and compliance issues related to the proposed food vehicle of bread. ${ }^{43}$ On 13 April 2007, FSANZ released a 95 page Issues Paper to seek public comment on some of the issues raised by the Ministerial Council in its request for a review. ${ }^{44}$ The public consultation period closed on 18 April 2007, only 5 days after the Issues Paper was released.

The First Review Report by FSANZ was then published on 23 May 2007. In 22 June 2007, the Ministerial Council issued a Communique stating that the Ministerial Council affirmed the draft Standard. ${ }^{45}$ The change to the Australia New Zealand Food Standards Code, to mandate fortification of bread-making flour with folic acid, was gazetted on 13 September 2007 to take effect exactly two years therefrom, namely 13 September 2009.

The end result is that from 13 September 2009, flour millers in Australia are required to ensure the fortification of wheat flour for bread making as required under Clause 4(2) of Standard 2.1.1 of the Australia New Zealand Food Standards Code. The flour is to contain 'no less than $2 \mathrm{mg} / \mathrm{kg}$ and no more than $3 \mathrm{mg} / \mathrm{kg}$ of folic acid'. ${ }^{46}$

\section{An ANALysis of Administrative LaW Issues Pertaining to the Decision}

A proper analysis of the decision-making process leading up to the introduction of mandatory folic acid fortification reveals irregularities and legal flaws in it, including the facts that:

1) FSANZ failed to follow the decision-making procedure as required by the FSANZ Act and Ministerial Council directions, and in particular failed to make its own scientific assessments;

\footnotetext{
43 FSANZ, Mandatory Fortification with Folic Acid (FSANZ Issues Paper, April 2007) $<$ http://www.foodstandards.gov.au/_srcfiles/P295_Issues\%20Paper_UPDATED_13\%20April $\% 2007$ FINAL.pdf $>$ at 6 November 2009.

${ }^{44}$ FSANZ, First Review Report - Proposal P295 - Consideration of Mandatory Fortification with Folic Acid (23 May 2007) <http://www.foodstandards.gov.au/_srcfiles/P295\%20 Folate\%20Fortification\%20FFR\%20+\%20Attach\%201\%20FINAL.pdf $>$ at $\overline{6}$ November 2009.

${ }^{45}$ Australia and New Zealand Food Regulation Ministerial Council, 'Joint Communiqué: Food Ministers Protect Public Health' (22 June 2007) <http://www.foodstandards. gov.au/newsroom/mediareleases/mediareleases2007/22june2007jointcommu3594.cfm $>$ at 6 November 2009.

${ }^{46}$ See above $n 6$.
} 
2) the decision made by FSANZ was based on advice that could be perceived as potentially biased; and

3) FSANZ failed to make an adequate assessment of the safety of the folic acid fortification for the wider population as well as failing to consider the various practicalities of implementation. ${ }^{47}$

The High Court and Federal Court of Australia each have jurisdiction to review government administrative decisions in accordance with the Administrative Decisions (Judicial Review) $A c t^{48}$ and the 1997 amendments to section 39B of the Judiciary Act. ${ }^{49}$ Due to the failure of FSANZ to follow proper processes, its decision could have been subjected to judicial review. However, no steps were taken to challenge either the outcome or process of the FSANZ Proposal P295 at the time the decision was made.

\section{A Was the Decision 'Administrative' or 'Legislative' in Character?}

For a decision to be judicially reviewed it must be of administrative character and not legislative. 50 'The distinction is essentially between the creation or formulation of new rules of law having general application and the application of those general rules to particular cases'.

The 'capacity of by-laws, like regulations, orders and rules, to assume either a legislative or an administrative character, is well recognized' ${ }^{52}$ Prima facie, the decision by FSANZ to approve the variation to the Food Standards Code in the form of a revised Standard 2.1.1, in order to authorise the mandatory folic acid fortification, has the character of an administrative decision.

However, the decision to approve a variation to the Food Standards Code could potentially be viewed by a court as a legislative decision and hence not

\footnotetext{
${ }^{47}$ The processes adopted by FSANZ run counter to principles of best practice for implementing public health interventions, such as those outlined by Gostin who states that, as public health interventions intrude on individual rights, public authorities need to rigorously evaluate the effectiveness of the proposed regulation and justify decisions. See Lawrence O Gostin, 'Public health law in a new century: Part III: Public Health Regulation: A systematic evaluation' (2000) 283 Journal of the American Medical Association 3118-22.

${ }^{48}$ Administrative Decisions (Judicial Review) Act 1997 (Cth) ('the ADJR Act').

${ }^{49}$ Judiciary Act 1903 (Cth) s 39B (1A).

${ }^{50}$ ADJR Act s 3(1).

${ }^{51}$ Bowen CJ, Northrop and Lockhart JJ in Minister for Industry and Commerce v Tooheys Ltd (1982) 4 ALD 661, 665.

${ }^{52}$ Bowen CJ, Northrop and Lockhart JJ in Minister for Industry and Commerce v Tooheys Ltd (1982) 4 ALD 661, 666.
} 
subject to judicial review. In determining the legal status of a decision by a government agency, the Federal Court case Queensland Medical Laboratory $v$ Blewet ${ }^{53}$ provides illustrative assistance, irrespective of the fact that it was not a case dealing with food standards. In that case, the Minister of Health and Community Services had been vested with the power to make determinations that would be included in the Schedule to the Health Insurance Act 1973 (Cth). The making of such a determination was held to be an exercise of legislative power whereas deciding not to exercise the power would have been an administrative decision. There is an analogy with the manner in which FSANZ can decide to abandon or to reject proposals or applications to vary the Food Standards Code. These decisions can be subject to merits review by the Administrative Appeals Tribunal under section 143(1) of the FSANZ Act and are clearly administrative decisions. By contrast, the actual decision to approve a variation to the Food Standards Code might not be the subject of merits review. ${ }^{54}$

Furthermore, Justice Sundberg of the Federal Court set out the following guidelines as to when a decision might be legislative rather than administrative, namely:

- Does the decision create a rule of general application?

- Must the decision be notified in the Gazette?

- Is the Authority required to undertake wide public consultation in preparation for making the decision?

- Is it the case that the decision is not reviewable by the AAT? and

- Does the decision have a binding legal effect once prepared $?^{55}$

While a variation to a Food Standard under the FSANZ Act bears some of those characteristics, it could nevertheless be argued that the approval of the variation to the Food Standards Code is an administrative decision because the ultimate legislative power to amend the Food Standards Code is vested in the Ministerial Council which has a right to reject a Standard before

\footnotetext{
53 (1988) 84 ALR 615.

54 The jurisdiction of the Administrative Appeals Tribunal does not extend to every administrative decision made by the government; its jurisdiction is created when the relevant statute specifically states when a decision can be reviewed by the AAT.

${ }^{55}$ See Sundberg J in SAT FM Pty Ltd v Australian Broadcasting Authority (1997) 46 ALD 305, 308-9.
} 
gazettal. ${ }^{56}$ Any draft variation approved by FSANZ does not immediately become part of the legislative instrument that is the Food Standards Code. Any variation must first be approved by the Ministerial Council before gazettal. It is this decision by the Ministerial Council to approve or reject a variation that is an exercise of legislative power whereas the consultation, drafting and scientific assessment undertaken by FSANZ in making its decision to approve a draft variation could be considered an exercise of administrative powers.

The possible grounds for an administrative review of the decision by FSANZ to introduce mandatory folic acid fortification Standard are set out below.

\section{B Ultra Vires}

To decide whether there are grounds for judicial review on the basis that the decision-maker has exceeded its statutory powers, it is necessary to interpret the statutory provisions granting the decision-maker the power. In this instance, the FSANZ Act does not only empower FSANZ to approve draft Standards but sets out very comprehensive procedures and considerations that must be complied with. Non-compliance with statutory mandated procedures will only invalidate a decision if a court finds that the legislature intended this to be the case:

An act done in breach of a condition regulating the exercise of a statutory power is not necessarily invalid and of no effect. Whether it is depends upon whether there can be discerned a legislative purpose to invalidate any act that fails to comply with the condition. ${ }^{57}$

The primary role of FSANZ under the FSANZ Act is to assess the safety of foods through risk analysis in order to protect the health of the public. ${ }^{58}$ When

\footnotetext{
${ }^{56}$ FSANZ Act s 86.

57 See McHugh, Gummow, Kirby and Hayne JJ in Project Blue Sky Inc $v$ Australian Broadcasting Authority (1998) 194 CLR 355, 388-9.

${ }^{58}$ Under s 18(1) of the Food Standards Australia New Zealand Act 1991 (Cth), the objectives of FSANZ (in descending order or priority) are: a) the protection of public health and safety; and $b$ ) the provision of adequate information relating to food to enable consumers to make informed choices; and c) the prevention of misleading or deceptive conduct. Under s 18(2) of the Food Standards Australia New Zealand Act 1991 (Cth), FSANZ must also consider the following factors in 'developing or reviewing food regulatory measures': a) the need for standards to be based on risk analysis using the best available scientific evidence; b) the promotion of consistency between domestic and international food standards; c) the desirability of an efficient and internationally competitive food industry; d) the promotion of fair trading in food; e) any written policy guidelines formulated by the Council for the purposes of this paragraph and notified to the Authority.
} 
considering mandatory fortification standards, FSANZ is required by Ministerial Council policy to take into account further, stricter considerations than the requirements under the FSANZ Act. For example, section 18(2) requires that FSANZ, in making any decision must take into account 'any written policy guidelines formulated by the Council'. ${ }^{59}$

Under the Ministerial Council Policy Guideline on Fortification of Food with Vitamins and Minerals, FSANZ had to determine in Proposal P295 the most effective mechanism to increase total folate intake in periconceptional women in order to reduce the incidence of NTDs from current levels in the Australian and New Zealand population. ${ }^{60}$ When making this determination, FSANZ was to consider the risks and benefits of an increased dietary folate intake to the general population. ${ }^{61}$

However, in the Draft Assessment Report, FSANZ merely stated:

On the basis of the Ministerial advice received in 2005 that mandatory fortification with folic acid is an effective strategy, FSANZ reduced the number of regulatory options being considered in this Draft Assessment Report ... ${ }^{62}$

This Report had narrowed consideration of regulatory options to 'maintenance of status quo' (including existing voluntary folic acid fortification) and mandatory fortification. Extension of voluntary folic acid permissions had been excluded from further consideration in this report. ${ }^{63}$

FSANZ never made an assessment of the risks and benefits of an increased dietary folate intake to the general population of Australia. Moreover, without conducting any analysis of its own on the most effective mechanism to increase dietary folate intake in the targeted population groups, FSANZ adopted the view that mandatory fortification was the most effective strategy and that all other options for increased folate intake in periconceptional women would not be considered. In doing so, FSANZ claimed that it was merely acting on the basis of 'Ministerial advice'. However, the Ministerial Council had in fact stated that:

\footnotetext{
${ }^{59}$ Food Standards Australia New Zealand Act 1991 (Cth) s 18(2)(e).

${ }^{60}$ FSANZ, 'Initial Assessment Report', above n 39, 11.

${ }^{61}$ Ibid.

${ }^{62}$ These regulatory options were: 'maintenance of status quo; extension of permissions for voluntary folic acid fortification; mandatory folic acid fortification; and increased health promotion and education strategies to increase folate intakes'. See FSANZ, 'Draft Assessment Report,' above n 40, ii.

${ }^{63}$ Ibid 11.
} 
- the prevalence of NTDs in Australia is relatively low and that the impact of fortification will have a small tangible effect; and

- there are no health benefits demonstrated to other segments of the non-target population through folic acid supplementation. ${ }^{64}$

The unknown 'Ministerial advice' referred to by FSANZ appears to have, as its source, advice in the form of a report prepared in June 2005 by the 'Expert Panel' that was convened by the AHMAC, entitled The Effectiveness of Mandatory Fortification as a public health strategy to increase nutrient intakes, with reference to iodine and folate. It was described in a sub-heading as 'Expert public health advice prepared for the Australian Health Ministers Advisory Council'.

This Expert Panel report focused principally on iodine fortification rather than folic acid fortification. The Expert Panel's consideration of folic acid fortification consisted of less than two pages of the report and simply provided, as an 'assessment', a matrix of tick boxes relating to the effectiveness, equity, efficiency, certainty, feasibility and sustainability of 5 different options. ${ }^{65}$

However, there was no analysis provided nor was any reasoning or consideration of evidence given in support of these 'ticks'. The mandatory folic acid fortification was thereby assessed to be the most effective public health strategy without any comparative review of other strategies. It was assessed to be efficient without any consideration of costs. It received a tick for certainty without any consideration of consumption patterns of carrier food types for targeted population groups.

Further, FSANZ decided that bread-making flour would be the most effective carrier for folic acid despite FSANZ also admitting that the real target population does not consume a large amount of bread:

Generally, lower proportions of women of child bearing age with low folic acid intakes consumed breads, breakfast cereals, yeast extract spreads, milks, fruit juices and soy beverage than those with high folic acid intakes. Additionally, women of child bearing age with low folic acid intakes, on average, consumed lower amounts of these foods than those with high folic acid intakes. There did not appear to be a food consumed

\footnotetext{
${ }^{64}$ FSANZ, 'First Review Report: Proposal P295: Consideration of Mandatory Fortification with Folic Acid' (23 May 2007) ('First Review Report') 22.

${ }^{65}$ Expert public health advice prepared for AHMAC, 'The effectiveness of mandatory fortification as a public health strategy to increase nutrient intakes, with reference to iodine and folate' (June 2005) s 4.2, 10-11.
} 
preferentially by women of child bearing age with low folic acid intakes that was feasible to fortify. ${ }^{66}$

To illustrate the same point even more clearly, FSANZ in its Final Assessment Report repeatedly singled out the indigenous community as requiring special attention because the rate of NTDs in the indigenous population was twice that of the general population. However, using the data supplied in Professor Bower's report ${ }^{67}$ concerning the total number of cases of neural tube defects prevented by mandatory folic acid fortification per year ${ }^{68}$ an estimated six prevented cases will be from the indigenous population. ${ }^{69}$ Furthermore, this estimate is actually based on the assumption that everyone in the indigenous community will consume bread, and a further assumption that the fortification of bread will result in a $100 \mu \mathrm{g}$ increase in daily folate intake.

This assumption that women of childbearing age from indigenous Australian communities consume bread was not supported by any evidence produced by FSANZ. FSANZ stated in the Final Assessment Report for P295 that only 2 per cent of the participants in the national nutrition surveys relied upon were indigenous Australian. ${ }^{70}$

It is clear that FSANZ, in its decision to implement mandatory fortification of bread-making flour with folic acid did not make any scientific assessment as to whether mandatory fortification was the most effective public health strategy. In fact, when the Ministerial Council rejected the Final Assessment Report on P295, one of the grounds was that FSANZ failed to adhere to Ministerial Council Policy by determining whether mandatory fortification was the most effective strategy or the only strategy available to address the public health issue. FSANZ replied in the First Review Report that 'The

${ }^{66}$ FSANZ, 'First Review Report', above n 64, 54 (Attachment 7).

${ }^{67}$ Carol Bower et al, 'Assessment of the potential effect of incremental increases in folic acid intake on neural tube defects in Australia and New Zealand' (2006) 30(4) Australian and New Zealand Journal of Public Health 369, 373.

${ }^{68}$ Table 5 of FSANZ 'Final Assessment Report', above n 9, 34 states that the estimated number of neural tube defect pregnancies prevented each year will be 26 for the whole Australian population (including non-indigenous and indigenous population).

69 The author has extrapolated this figure from the data in the Final Assessment Report for Proposal P295. If mandatory folic acid fortification will prevent 26 neural tube defect births a year out of a total population of 21 million people and the estimated indigenous population of Australia is approximately 480000 , then proportionally the number of cases prevented will possibly be 6 . However this figure may vary significantly: for example, although there is a higher prevalence of neural tube defects in indigenous communities, there is no evidence as to whether the food carrier (bread) can deliver the nutrient to periconceptional women in indigenous communities.

${ }^{70}$ FSANZ, 'Final Assessment Report', above n 9, 26-7. 
Ministerial Council has made it clear that under the terms of the policy guideline, it is a matter for Ministers to determine whether mandatory fortification is the most effective strategy'. ${ }^{71}$ A clear interpretation of this conduct of FSANZ is that it was seeking to 'pass the buck' back to the Ministerial Council, whereas the Ministerial council was under the impression that the decision could still be made by FSANZ.

There was no consideration of whether mandatory fortification was the most effective public health strategy other than the two pages in the Expert Panel Report. The failure to make a proper consideration of the facts could amount to the decision being said to have been made ultra vires.

\section{Perceptions of Apprehended Bias}

There are common law grounds for judicial review where administrative decision-makers do not approach their task with a degree of neutrality. Furthermore, they must appear to be open-minded to the reasonable observer. 'When suspected prejudgement of an issue is relied upon to ground the disqualification of a decision-maker, what must be firmly established is a reasonable fear that the decision-maker's mind is so prejudiced in favour of a conclusion already formed that he or she will not alter that conclusion irrespective of the evidence or arguments presented to him or her. ${ }^{72}$ The test for determining whether a decision-maker should disqualify himself or herself by reason of apprehended bias is "whether a fair-minded lay observer might reasonably apprehend that [the judge] might not bring an impartial and unprejudiced mind to the resolution of the question [the judge] is required to decide'. ${ }^{73}$

While FSANZ referred to the findings of an Expert Panel, which did not provide detailed reasons or evidence to support its findings, ${ }^{74}$ it should be noted that this Expert Panel consisted of four members of whom Professor Fiona Stanley was one and Professor Creswell Eastman was another. Professor Stanley is a member of the 'Leaders Group' of the 'Flour Fortification Initiative'(FFI). ${ }^{75}$ Professor Eastman was Chairman of the Division of Laboratory Medicine at Westmead Hospital, and Westmead

\footnotetext{
${ }^{71}$ FSANZ, 'First Review Report', above n 64, 7 and 22.

${ }^{72}$ See Gaudron and McHugh JJ in Laws v Australian Broadcasting Tribunal (1990) 170 CLR 70, 100.

${ }^{73}$ Ebner v Official Trustee in Bankruptcy (2000) 205 CLR 337.

${ }^{74}$ FSANZ, 'First Review Report', above n 64, 22.

${ }^{75}$ Flour Fortification Initiative <http://www.sph.emory.edu/wheatflour/leadership.php $>$ at 19 November 2009.
} 
Hospital has been a named 'Partner' of the FFI. ${ }^{76}$ The FFI is an international network whose key aims are publicly summarised at its website:

The Flour Fortification Initiative (FFI) is a network of individuals and organizations working together to make micronutrient fortification of flour produced by large roller mills standard practice. ${ }^{77}$

The author is not suggesting that any members of the Expert Panel were personally biased in the decision-making that occurred on that Expert Panel or that the Report made by the Expert Panel was based on any pre-judgment of the issues being considered. However, from an administrative law perspective, a legal issue might have existed at the time in relation to whether membership of this panel of experts gave rise to apprehended bias because of the abovementioned associations by some members of the Expert Panel. In turn, it could be argued that FSANZ, by relying on the Expert Report, relied on information that may have been subject to a perception of bias or apprehended bias and that FSANZ failed to make its own independent objective scientific assessment preliminary to the introduction of mandatory folic acid fortification. These legal issues were never raised because no proceedings for judicial review of the administrative decision were initiated before the expiry date for any such proceedings. ${ }^{78}$

\section{Standard Based on Flawed Safety Assumptions}

The Australian flour milling industry indicated that it was technically impossible to ensure that folic acid would be able to be added in a consistent manner to the flour at the levels set out in the new Standard. ${ }^{79}$ Despite this, FSANZ simply made the assumption that the levels of folic acid in the food will always be at the prescribed levels.

No consideration was given by FSANZ to the safety of bread with folic acid levels much higher than the maximum level set out in the Standard. Excessive folic acid levels are likely because of the practical difficulty of administering the correct dosage within the prescribed narrow range of a maximum and minimum level.

\footnotetext{
${ }^{76}$ Flour Fortification Initiative < http://www.sph.emory.edu/wheatflour/partnerlinks.php $>$ at 19 November 2009.

77 Flour Fortification Initiative website: What is FFI? <http://www.sph.emory. edu/wheatflour/whatisffi.php> at 22 December 2008.

${ }^{78}$ See below $n 88$.

${ }^{79}$ FSANZ, 'Final Assessment Report', above n 9, 94 (Attachment 2).
} 
In its Final Assessment Report, FSANZ said that the dosage level would be 80-180 micrograms per 100 grams of bread, which FSANZ stated would result in a 14 per cent decrease in the occurrences of NTDs ${ }^{80}$ In the Final Assessment Report, the reference in the Decision ${ }^{81}$ to 'mandatory fortification of bread' (rather than bread-making flour) showed a degree of confusion by FSANZ as to what was being fortified. This caused the Ministerial Council to ask FSANZ to review its proposed food vehicle. FSANZ in its First Review Report then stated that the dosage that would be required for mandatory folic acid fortification would be a minimum of 200 micrograms and a maximum of 300 micrograms per 100 grams of flour. ${ }^{82}$ FSANZ then made it clearer that the responsibility for mandatory folic acid fortification of bread-making flour in Australia would be at the flour mill rather than the bakery. ${ }^{83}$ Yet the statistic still remained at 14 per cent for the decrease of occurrences of NTDs. This sudden change in the decision was made without any further scientific assessment, arguably highlighting the uncertainties within FSANZ.

\section{E Failure to Consider the Practicalities of Implementation}

In its First Review Report, FSANZ estimated the 'costs to industry as \$7.9 million up-front and \$1.1 million per year', based on the 'assumption that there will be no need to change any of the flour milling process' ${ }^{84}$

However, in a submission prepared by the Flour Millers Council of Australia ('FMCA'), the FMCA advised FSANZ that the real cost was estimated to be \$28.6 million up-front and \$12.1 million per year. ${ }^{85}$ This figure was said to be inclusive of extra equipment and analytical testing costs. FSANZ clearly disregarded these costings of the new monitoring, audit and analysis methods required for flour millers to make any proper attempt at compliance.

\footnotetext{
${ }^{80}$ FSANZ, 'Final Assessment Report,' above n 9, iii and 17.

81 The Decision states: 'Mandatory fortification of bread with folic acid is the preferred approach in Australia and New Zealand to further reduce the incidence of NTDs. The proposed level of mandatory fortification is $80-180$ micrograms $(\mu \mathrm{g})$ of folic acid per 100 grams of bread.' Bread is defined as: 'the product made by baking a yeast-leavened dough prepared from one or more cereal flours or meals and water': FSANZ, 'Final Assessment Report,' above n 9, iii.

82 FSANZ, 'Draft Assessment Report for Proposal P295 - Consideration of Mandatory Fortification with Folic Acid' (3 July 2006) 63

${ }^{83}$ FSANZ, 'First Review Report,' above n 64, 4.

${ }^{84}$ Ibid 52. Maberly and Stanley argue that folic acid fortification of flour is 'cheap' and that because thiamine is already a required additive in flour, the costs of preparation and of administering quality control of the process are small: above n 17, 342 .

${ }^{85}$ FSANZ, 'First Review Report', above n 64, 51.
} 
Further, FSANZ referred to its own international comparative costing data as a basis for measuring the likely cost of implementation to the Australian flourmilling industry. ${ }^{86}$ These international cost figures ought to have been considered irrelevant to the Australian position because the fortification requirements in other countries did not set a maximum level. FSANZ itself did, in fact, acknowledge that the Australian mandatory folic acid fortification Standard will be different from the standard in every other country because all other countries simply set a minimum level of fortification. FSANZ, by contrast, decided to set a folic acid content falling between a minimum and maximum level. ${ }^{87}$ The setting of a range of acceptable folic acid levels in the flour would require a much greater investment by the flour-milling industry in testing and equipment to ensure that neither the maximum nor minimum level is exceeded. ${ }^{88}$

\section{F Administrative Challenges to FSANZ Decision}

For the FSANZ decision to have been subject to judicial review, an action would need to have been brought within 28 days of the decision being made. ${ }^{89}$ However no action was commenced. Commentators have also acknowledged that judicial review is normally a strategy of last resort, due to the fact that an administrative decision is only reviewable if it was made unlawfully. An alternative to judicial review would be for an urgent proposal to be made to amend the Food Standards Code again. Logically, the Ministerial Council could be an appropriate proponent if these issues were to be re-considered.

\section{iV Restrictions on Causes of Action Avallable to INJURED CONSUMERS}

The uncertainty surrounding the health risks and impacts of mandatory folic acid fortification on the broader public, raises issues of legal liability and the remedies available to the injured consumer. However, in the current Australian legal framework there are a number of hurdles that any injured consumers would have to overcome in order for a court to grant them a right to compensation. It is not the intention of this paper to explore in depth the law of torts and product liability; however it is necessary to consider these causes of action very briefly in order to establish how an injured consumer might be compensated and by whom.

\footnotetext{
${ }^{86}$ Ibid 52-3.

${ }^{87}$ Ibid 53.

${ }^{88}$ FSANZ, 'Final Assessment Report,' above n 9, 94 (Attachment 2).

${ }^{89}$ Administrative Decisions (Judicial Review) Act 1977 (Cth) s 11(3).
} 


\section{A Liability of the Flour Millers and Bread Manufacturers}

The causes of action available to an injured consumer who seeks to sue the flour millers would include the tort of negligence and breach of the Trade Practices Act 1974 (Cth) caused by a defective product. ${ }^{90}$

Beginning with Donoghue $v$ Stevenson, ${ }^{91}$ there is a long line of precedents establishing a duty of care between the manufacturer of a product and its final consumer. However, for the flour manufacturers to be under a duty to cease fortifying bread-making flour with folic acid, there must be sufficient proof or consensus amongst the scientific community regarding its negative effects. In the Victorian Supreme Court case of Thompson v Johnson \& Johnson, ${ }^{92}$ a woman had suffered toxic shock syndrome caused by using tampons manufactured by the defendant. The type of tampon in question had been used all over the world for 80 years. The trial judge and appeal court found that, while the woman's injury was caused by the defective product, the scientific evidence at the time of the injury had not yet reached the point where there would be a duty of care to put warnings on the label. It might be argued that the point where the flour millers could become liable for injuries resulting from over-exposure to folic acid is the point in time where the consensus based on scientific evidence changes from declaring folic acid safe to stating that it could cause serious injury or illness.

Under the Trade Practices Act, products are defective when 'their safety is not such as persons generally are entitled to expect' ${ }^{93}$ There are two defences that manufacturers might use if accused of supplying a defective product: (1) lack of scientific evidence; and (2) compliance with a mandatory standard.

Section 75AK(1)(c) of the Trade Practices Act states:

In a liability action, it is a defence if it is established that:

the state of scientific or technical knowledge at the time when they [the goods] were supplied by their actual manufacturer was not such as to enable that defect to be discovered.

Science can therefore be used as a defence against consumer claims if it can be proven that the level of scientific knowledge at the time when a

\footnotetext{
90 Trade Practices Act 1974 (Cth) s 75AC (for the definition of defective goods) and s $75 \mathrm{AC}(4)(\mathrm{b})$.

${ }^{91}$ Donoghue v Stevenson [1932] AC 562.

92 [1991] 2 VR 449.

${ }^{93}$ Trade Practices Act 1974 (Cth) s 75AC(1).
} 
manufacturer fortified wheat-flour was not such that it could be shown that elevated levels of folic acid could cause injury. Similarly, the flour millers may be able to argue that supporting science at the time of the injury was not at a point where there was a duty to act otherwise than they did.

A second defence exists under section $75 \mathrm{AK}(1)(\mathrm{b})$ of the Trade Practices Act which provides that:

In a liability action, it is a defence if it is established that:

...

[the product] had the defect only because there was compliance with a mandatory standard.

On the basis of this statutory defence, flour millers would be liable for injuries arising from over-exposure to folic acid if they had not complied with Standard 2.1.1 (by, for example, exceeding the maximum dosage of folic acid to be added to the flour).

\section{B Liability of Food Law Enforcement Agencies}

The bodies responsible for ensuring that the flour millers comply with the Food Standards Code are in fact the food authorities of each State and Territory. Each State and Territory has passed legislation (in accordance with the Food Regulation Agreement signed by the Australian State, Territory and Commonwealth governments in November 2000) making it a criminal offence for a person or corporation to breach the Food Standards Code. ${ }^{94}$

While these bodies have a clear mandate to protect consumers from unsafe food, they cannot be held legally responsible for food products that are only unsafe due to their compliance with the Food Standards Code. However, if the state of scientific knowledge is such that it is clear that enforcement of Standard 2.1.1 could cause injury, or that the food enforcement agency has breached an express statutory duty, it may be possible for a consumer to sue a food authority successfully for that breach.

Yet there are additional legal hurdles in establishing a duty of care on the part of government bodies. One difficulty is that posed by the judgements in the High Court decision of Graham Barclay Oysters Pty Ltd $v$ Ryan. ${ }^{95}$ The

\footnotetext{
${ }^{94}$ See Food Act 2001 (ACT) s 27; Food Act 2004 (NT) s 20; Food Act 2003 (NSW) s 21; Food Act 2006 (Qld) s 14; Food Act 2001 (SA) s 21; Food Act 2003 (Tas) s 21; Food Act 1984 (Vic) s 16; Food Act 2008 (WA) s 22.

${ }^{95}$ (2002) 194 ALR 337.
} 
statutory provisions must create 'a relationship between the authority and a class of persons that, in all the circumstances, displays sufficient characteristics answering the criteria for intervention by the tort of negligence'. ${ }^{96}$ The extra elements that must exist to create a duty of care between a food authority and a consumer injured by excess folic acid consumption would be:

The degree and nature of control exercised by the authority over the risk of harm that eventuated ... the degree of vulnerability of those who depend on the proper exercise by the authority of its powers ... and the consistency or otherwise of the asserted duty of care with the terms, scope and purpose of the relevant statute. ${ }^{97}$

The case of Graham Barclay Oysters Pty Ltd v Ryan also highlights the issue of justiciability. High Court precedent distinguishes between a 'public duty [...] to give consideration to the exercise of a power, and a legal duty, owed to a citizen, to exercise the power' ${ }^{98}$ In that case, the failure by the State government to exercise a power that may have prevented the injury was held to be a policy decision (a decision which involves budgetary, social or political factors) which is not subject to a statutory duty of care, as opposed to an operational decision which can be the subject of a negligence action:

Here we are concerned with the problem of deciding, in a case where the government had certain powers, whether it is accountable, through the law of negligence, for not exercising its powers, or for not exercising them sufficiently. To apply that form of legal accountability requires the identification, not merely of a power, but also a duty; a duty of care owed to a citizen or a class of citizens. ${ }^{99}$

These considerations of justiciability have now been codified in statute in a number of Australian State and Territory jurisdictions, for example in sections 42 and 43 of the Civil Liability Act 2002 (NSW) or section 83 of the Wrongs Act 1958 (Vic).

\section{Liability of FSANZ}

As discussed above in Part III of this paper, FSANZ has clear obligations under the FSANZ Act to protect 'public health and safety' and to base its

\footnotetext{
${ }^{96}$ Ibid 375.

${ }^{97}$ Ibid 376 (emphasis added).

${ }^{98}$ Ibid (Gleeson CJ).

${ }^{99}$ Ibid.
} 
decisions on 'the best available scientific evidence'. ${ }^{100}$ While certain failures by FSANZ to adhere to protocols and proper process in the course of its administrative function under FSANZ Proposal P295 could give rise to judicial review of the decision, section 151 of the FSANZ Act exempts FSANZ itself, any person assisting FSANZ, any member of the Board of FSANZ and the Commonwealth government from any civil or criminal proceeding 'in relation to any loss or injury directly or indirectly sustained by a person' because of the consumption of, or other dealing with, food.

Under section 7(1)(g) of the FSANZ Act, FSANZ has a duty to "co-ordinate the monitoring, surveillance and enforcement of activities relating to food available in Australia.' In its First Review Report, ${ }^{101}$ FSANZ addressed the issue of monitoring on a single page, stating that it will contribute to the monitoring of fortified foods by tracking changes in the food supply for fortified foods in key categories. ${ }^{102}$ It would be a failure of FSANZ to perform its essential duties if there were to be inadequate monitoring and evaluation of mandatory folic acid fortification since the long term health implications of elevated folic acid levels are not known. ${ }^{103}$

The previous experience with voluntary folate fortification, where few resources were provided for monitoring, does not provide a great deal of assurance to consumers that FSANZ will establish sufficient monitoring. ${ }^{104}$

Furthermore, FSANZ has no power of enforcement in relation to ensuring compliance by flour millers. The powers to enforce any food standard in the Food Standards Code are principally the responsibility of State and Territory bodies or their delegated officers (including local government officers). Accordingly, FSANZ is not even in a legal position to monitor compliance.

FSANZ might argue that, even though it has a duty to monitor scientific developments in relation to adverse health effects of the mandatory folic acid fortification, any failure by FSANZ to comply with its statutory duties ought not to give rise to any compensation against FSANZ. This is because any civil

\footnotetext{
${ }^{100}$ FSANZ Act s 18.

${ }^{101}$ This document of 69 pages was issued on 23 May 2007, above n 64 .

102 These key categories are: 1) updating the Australian national food composition databases; 2) tracking labelling changes on fortified foods; 3) tracking changes in food consumption patterns of key food categories that are likely to be fortified for different demographic groups; 4) producing regular literature reviews relating to risks/benefits of folate and folic acid in the diet; and 5) researching changes in consumers' attitudes and behaviour towards fortified foods: FSANZ, 'First Review Report', above n 64, 54.

${ }^{103}$ Mark Lawrence, above n 21, 70.

104 Ibid.
} 
or criminal suit against FSANZ will first have to address the statutory immunity conferred by section 151 of the FSANZ Act.

\section{Statutory Reductions of Damages}

Since 2002, Australian jurisdictions have passed laws that imposed limits on particular heads of damages in different causes of action including the tort of negligence and product liability under the Trade Practices Act. ${ }^{105}$ Therefore, even in the event of an aggrieved consumer having a right to compensation arising from one of the abovementioned causes of action, he or she may not be compensated adequately or to the full extent of the injury.

For example, the Trade Practices Act has been amended to preclude the recovery of damages where the non-economic loss suffered by the plaintiff amounts to less than the threshold of 15 per cent of the 'most extreme case'. ${ }^{106}$ On top of this threshold, any damages for non-economic loss have been capped at a statutory amount of $\$ 250000$ (indexed to the Consumer Price Index). ${ }^{107}$

\section{E The State of Class Actions in Australia}

Another potential hurdle to any class of consumers wanting to take action for injuries suffered as a direct result of the creation of the mandatory folic acid fortification Standard is the history of class actions in Australia. The first legislative class action regime was enacted in 1992 as Part IVA of the Federal Court Act 1976 (Cth) which took effect on 5 March 1992. State legislatures have by and large followed suit; for example the relevant amendments to the Supreme Court Act 1986 (Vic) took effect from 1 January 2000.

The amendments to the Federal Court Act were prompted by the Law Reform Report 46, Grouped Proceedings in the Federal Court. The purpose of the amendments was to give access to justice to individuals whose individual claims were too small to warrant the costs of litigation and to deal efficiently with the situation where a large number of persons wish to sue a respondent over the same breach of law.

\footnotetext{
${ }^{105}$ See, for example, John Chu, 'Analysis and Evaluation of Victorian Reform in General Damages for Personal Injury under the Tort of Negligence' (2007) 10(2) Deakin Law Review 125.

${ }^{106}$ Trade Practices Act 1974 (Cth) s 87S.

${ }^{107}$ Trade Practices Act 1974 (Cth) s 87M.
} 
Class actions have been restricted by a series of judicial decisions resulting from certain prevailing attitudes, namely that class actions will lead to entrepreneurial litigators and a US style of litigation. Callinan J said in Mobil Oil Australia Pty Ltd v Victoria ${ }^{108}$ that class actions are likely to: aggravate proceedings that are oppressive to defendants; give rise to entrepreneurial litigation; lead to the proliferation and prolonging of court proceedings; undesirably substitute private for public law enforcement; and be contrary to the public interest.

Murphy and Cameron ${ }^{109}$ have identified a number of judicial decisions that have further restricted the use of class action regimes in Australia, such as Bright $v$ Femcare, ${ }^{110}$ King $v$ GIO Australia Holdings Ltd ${ }^{111}$ and Tobacco Control Coalition Inc v Phillip Morris (Australia) Ltd. ${ }^{112}$

\section{Government Compensation Schemes}

If compensation were not readily available in private legal actions or class actions for injury caused by a mandatory fortification of food, one alternative to be considered at the Commonwealth government level would be for a compensation payment to be made under the Scheme for Compensation for Detriment caused by Defective Administration ('the CDDA Scheme').

This is a discretionary compensation scheme that is administered through the Federal Department of Finance and Deregulation but operated on the basis of authority provided to individual portfolio Ministers in the Federal

\footnotetext{
${ }^{108}$ Mobil Oil Australia Pty Ltd v Victoria (2002) 211 CLR 1.

${ }^{109}$ See Bernard Murphy and Camille Cameron, 'Access to Justice and the Evolution of Class Action Litigation in Australia' (2006) 30 Melbourne University Law Review 399.

${ }^{110}$ Bright v Femcare (2001) 188 ALR 633 - class action provisions require that the plaintiffs have sufficient common ground between their cases to warrant them being heard together. This has led to mass interlocutory applications before even a defence has been lodged. In Bright $v$ Femcare there were two Full Court Federal Court appeals and two appeals to the High Court simply over whether the matter could be heard as a class action. The applicants in the end abandoned the attempt, deciding to have their cases heard individually.

${ }^{111}$ King v GIO Australia Holdings Ltd [2000] FCA 1543 - the lead representative in this case had a claim only for $\$ 3000$ out of $\$ 97$ million. In some cases, judges have required known members of a class action to provide security for costs should they lose. However, for people with small claims, the security for costs may be greater than the individual claim. Also such requirements may force wealthier members of the class to shoulder responsibility as lead representative that they do not want.

112 Tobacco Control Coalition Inc v Philip Morris (Australia) Ltd [2000] FCA 131 - the respondents sought costs orders for opposing solicitors to be held responsible for adverse costs, simply because they 'promoted' the litigation. As a consequence the solicitors withdrew.
} 
government. ${ }^{113}$ Payments under the CDDA Scheme are made in reliance on the executive power arising from section 61 of the Australian Constitution and section 33 of the Financial Management and Accountability Act 1997 (Cth). Applications for compensation are dealt with by government on a discretionary basis and payments are usually considered either as 'ex gratia payments' or 'act of grace payments'.

The discretionary nature of the CDDA Scheme would make it difficult for a government to address a large volume of similar claims arising from the same government action by the same government agency.

One example of a government compensation scheme for potential injuries arising from a public health intervention is the Pituitary Hormones Trust Account, created in 1994 after it was established that the governmentapproved Australian Human Pituitary Hormones Program exposed its participants to the contracting of Creutzfeldt-Jakob Disease. Out of 2163 people treated in the official program, there have been five reported deaths from Creutzfeldt-Jakob disease. ${ }^{114}$ The Pituitary Hormones Trust Account was created by the Federal government to provide a support group network and a counselling service for sufferers and to cover medical costs and other care needs if any further pituitary hormone recipients contract Creutzfeldt-Jakob Disease.

Cases involving military personnel, where plaintiffs have sought compensation for injuries arising from mandatory government impositions, are also possibly analogous to the situation in question here. Compensation schemes for the military exist under the provisions of the Veterans' Entitlements Act 1986 (Cth). For example, it has been reported that the Repatriation Medical Authority is currently reviewing its decision to exclude Gulf War illness from the Veterans' Entitlements Act. ${ }^{115}$ Gulf War illness has been linked to the forced administration to soldiers of pyristigmine bromide pills by Australian authorities in order to protect the soldiers from nerve gas. (The illness has also been linked to exposure to sarin gas and other chemicals used in the first Gulf War).

A more favourable outcome has been obtained in the United States in relation to the experience of the Agent Orange defoliant by US military personnel. In

\footnotetext{
113 See Finance Circular No. 2006/05 issued by the Federal Department of Finance and Deregulation, last updated 17 April 2008.

114 See Department of Health and Ageing website, <http://www.health.gov.au/internet/ main/publishing.nsf/Content/health-pubhlth-strateg-phi-index.htm> at 14 January 2009.

${ }^{115}$ See Leo Shanahan, 'About-face likely on Gulf illness', The Age, (Melbourne) 15 January $2009>$ at 15 January 2009.
} 
1984, following the Vietnam War, manufacturers of Agent Orange were ordered to pay $\$ 184$ million in compensation to US Vietnam War veterans. ${ }^{116}$ The US government had claimed sovereign immunity from liability for the mandatory use of Agent Orange. The exposure of military personnel to Agent Orange has been associated with diseases such as type II diabetes mellitus, prostate cancer, and lung cancer, among other illnesses. The issue of compensation for injury occurring as a result of conditions imposed by the government was resolved in this particular instance when the US Congress enacted the Agent Orange Act of 1991. This Act provided that veterans who served 'in the Republic of Vietnam' from 9 January 1962 to 7 May 1975 would be presumed to have been exposed to Agent Orange. This presumption has therefore avoided the need for these plaintiffs to satisfy the legal burden of proving that the government action caused their injury. ${ }^{117}$

\section{Conclusion ANd the Need for LAW Reform}

As Professor Lawrence Gostin has stated:

While government has responsibility to ensure the conditions for health, it cannot overreach in a democratic society. This leads to one of the most complicated problems in the field, which is how to balance the collective good achieved by public health regulation with the resulting infringements of individual rights and freedoms. ${ }^{18}$

Gostin contends that public health interventions need justification because they intrude on individual rights and incur economic costs, and he provides a 5 -step test that public authorities need to satisfy when undertaking public health interventions to justify implementing mandatory regulations: (1) There must be a significant risk based on scientific evidence; (2) The intervention must be effective; (3) The economic costs of the intervention must be reasonable; (4) The human rights burdens of the intervention must be reasonable; and (5) The benefits, costs and burdens of the intervention must be fairly distributed. ${ }^{119}$

\footnotetext{
${ }^{116}$ In Australia in the same year, veterans of the Vietnam War also obtained compensation from the manufacturers of Agent Orange.

${ }^{117}$ National Veterans Legal Services Program, 'NVLSP Attorneys win Haas v Nicolson "Blue Water" Navy Veterans entitled to the presumption of exposure', $<$ http://www.nvlsp.org/Information/ArticleLibrary/AgentOrange/AO-hassvnicholson.htm $>$ at 10 December 2008.

${ }^{118}$ Lawrence Gostin, above n 47, 3122.

119 Ibid.
} 
The failure by the Ministerial Council or FSANZ to make a proper assessment as to whether mandatory fortification was the most effective public health strategy to address folate deficiency has resulted in a public health intervention that is not based on scientific evidence, that is not the most efficient option, and that appears to have imposed human rights burdens that could be described as unreasonable.

There were clear failures in the decision-making processes involved in FSANZ Proposal P295 that resulted in the variation to Standard 2.1.1 so as to impose mandatory folic acid fortification of bread-making flour. Apart from questioning the need for public health interventions involving mandatory fortification of food, one should consider whether the mandatory folic acid fortification demonstrates a legislative inadequacy in the system of administrative assessment and the need for a more comprehensive system of review for this type of variation to a food standard. Furthermore, if the policy of mandatory fortifications of food is to continue, then any decision by government agencies to use the food supply as a way of imposing a mandatory medication of the population ought to be based on principles that include the following:

1) Any such decision ought to be made in accordance with a proper process (in the case of the Food Standards Code, section 18 of the FSANZ Act requires standards to be 'based on risk analysis using the best available scientific evidence') and ought to be capable of judicial review;

2) Any form of mandatory fortification must be properly targeted and be accompanied by a satisfactory monitoring regime to ensure control of the levels of exposure to the fortifying substance and to identify any potential adverse health consequences as a result of exposure; and

3) Any mandatory fortification regime must make provision for coexisting and concurrent legal rights and remedies that can overcome the current hurdles in the Australian legal system facing injured consumers. Given the inadequacies that have been identified above, a court may feel compelled in the future to consider the possible recognition of further legal rights or additional statutory duties that might stand outside or beyond the law of negligence and overcome the defence of statutory immunity where it can be proven there was an inadequate scientific consensus when the fortification was introduced into law. 
Furthermore, additional legislative provision should be considered for compensation to be made available in the circumstances of a change in the scientific consensus pertaining to a mandatory food fortification to operate in conjunction with the standard that imposes the mandatory fortification of the food. 